\title{
Clinical characteristics and neurophysiology features of amyotrophic lateral sclerosis patients at Sanglah Hospital Denpasar
}

\author{
I Made Odie Lastrawan, Komang Arimbawa, Ni Made Dwita Pratiwi \\ Neurology Department, Faculty of Medicine, Udayana University, Sanglah General Hospital, Denpasar, Indonesia
}

\begin{abstract}
Background. Amyotrophic lateral sclerosis (ALS) is a one of motor neurons disease. The Incidents in Europe are 2.6 per 100,000 people per year and in the United States, more than 5,600 are diagnosed each year. The death was reportedly 2 per 100,000 people per year. In Sanglah Hospital there are no study that described the characteristics clinical and neurophysiology of ALS at Sanglah Hospital.

Objective. To find the characteristics of ALS based on clinical and neurophysiology of ALS at Sanglah Hospital in terms of demography, clinical, Nerve Conduction Studies (NCS) and Electromyography (EMG).

Methods. Retrospective descriptive study using medical records of patients in neurology polyclinic at Sanglah Hospital from January until December, 2018.

Results. From 14 ALS patients with average age of 47 years old, men and women same amount, high school $71.4 \%$, unemployed $50 \%$, and married $92.8 \%$. Symptoms first appeared with an average age of 42 years with complaints of lower limb weakness $64.3 \%$. The diagnosis of ALS with the symptom UMN and LMN on bulbar and 2 spinal region $71.4 \%$, and symptom with the UMN and LMN on 3 spinal region $28.6 \%$. Results of motor and sensory NCS were normal, type axional and mixed neuropathy. Characteristics of EMG were PSW +4, fibrillation +4, MUAP: high amplitude (giant potential), widened duration, polyphasic phase, incomplete IP recruitment in all patients (100\%) although in different muscles of the examined patient.

Conclusions. Characteristics from 14 patients ALS in 2018 at Sanglah Hospital indicate that patients have a good prognosis.
\end{abstract}

Keywords: amyotrophic lateral sclerosis, electromyography, nerve conduction studies

\section{INTRODUCTION}

Amyotrophic lateral sclerosis (ALS) is a neurodegenerative disease that attacks motor neurons. Amyotrophy indicates the presence of muscle fibre atrophy, innervated by degenerating anterior horn cells, causing muscle weakness and fasciculation. Lateral sclerosis indicates hardening of the corticospinal tracts lateral and anterior where the motor neurons in the area degenerate through the process of gliosis. Through this combination of terms, it can be illustrated that in this disease a mixed lesion of upper motor neuron and lower motor neuron occurs (1-3).
The incidence of ALS in Europe is around 2.6 people per 100,000 per year (4). In the United States, more than 5,600 are diagnosed each year (more than 1.5 per 100,000 per year), and up to 30,000 Americans are currently affected. ALS is responsible for two deaths per 100,000 Americans per year $(5,6)$. ALS is classified as a rare disease designated by the FDA as an "orphan" disease (affecting less than 200,000 people in the United States), but it is the most common motor neuron disease. One or two in 100,000 people develop ALS each year. $(1,2)$

ALS is a degenerative disease that is most commonly found in the motor neuron system. ALS was 
first described in 1874 by a French neurologist named Jean-Martin Charcot and ALS is also known as Charcot's disease $(1,3)$

Sanglah Hospital Denpasar, which is a referral center hospital, plays an active role in diagnosing ALS patients. Currently, there are no studies that discuss the characteristics of ALS patients at Sanglah Hospital, both in terms of epidemiology and clinical symptoms. Therefore, this study was conducted to determine the clinical characteristics and neurophysiology of ALS patients at Sanglah Hospital Denpasar.

\section{MATERIAL AND METHOD}

This study was a retrospective descriptive design for all neurological patients with ALS who came to the polyclinic and inpatients who underwent electromyography (EMG) examinations at Sanglah General Hospital, Denpasar. Data collection was through patient medical records for the period $1^{\text {st }}$ January until 31 December 2018. The inclusion criteria were all neurological patients with ALS suspicion who came to the polyclinic and who underwent an ENMG examination at Sanglah Hospital Denpasar. Exclusion criteria were: patients with other types of motor neurone disorders (syringomyelia, cervical spondylitis, motor neuropathy, hyperthyroid myopathy, spinal muscular atrophy, multiple entrapment neuropathies, multiple sclerosis and multifocal vascular disease) (1). Data obtained were tabulated and processed using the SPSS version of the program. 20 to get research results.

\section{RESULTS}

In this study, data were obtained in the form of the ALS incidence rate in Sanglah Hospital for the period January until December 2018, with total of 14 patients.

The average age of ALS patients was 47 years, with a minimum age of 24 years and a maximum age of 63 years. The incidence rates for female and male sex are the same. The most jobs found are not working 7 patients (50\%), 4 people work as farmers, 2 self-employed people and 1 civil servant (PNS). Most data were 13 patients (92.8\%) with a married status and the latest education was high school graduates, namely 10 patients $(71.4 \%)$ (table 1$)$.

TABLE 1. Demographic characteristics of ALS patients

\begin{tabular}{|l|c|c|}
\hline Characteristic & Total & Percentage (\%) \\
\hline Age (median) & 47 & \\
\hline Gender & & \\
\hline Male & 7 & 50 \\
\hline Female & 7 & 50 \\
\hline Profession & & \\
\hline
\end{tabular}

\begin{tabular}{|l|c|c|}
\hline Characteristic & Total & Percentage (\%) \\
\hline Entrepreneur & 2 & 14.3 \\
\hline Civil servants & 1 & 7.2 \\
\hline Not work & 7 & 50 \\
\hline Farmer & 4 & 21.5 \\
\hline Marriage status & & \\
\hline marry & 13 & 92.8 \\
\hline not marry/ divorce & 1 & 7.2 \\
\hline Education & & \\
\hline Elementary school & 3 & 21.4 \\
\hline High school & 10 & 71.4 \\
\hline University & 1 & 7.2 \\
\hline
\end{tabular}

TABLE 2. Early clinical symptoms

\begin{tabular}{|c|c|c|}
\hline Characteristic & total & Percentage (\%) \\
\hline $\begin{array}{c}\text { age } \\
\text { median }\end{array}$ & 42 & 35.7 \\
- Weakness of the Upper \\
$\begin{array}{c}\text { Extremity } \\
\text { - Weakness of the lower } \\
\text { Extremity }\end{array}$ & 5 & 64.3 \\
\hline
\end{tabular}

It can be seen from the data in Table 2 that the mean interval for patients to develop symptoms until finally diagnosed as ALS 5 years (baseline at mean age 42 years) with weakness in the lower extremities appeared first in 9 patients (64.3\%).

From clinical signs, upper motor neuron and lower motor neuro signs were obtained in the bulbar region and at least 2 spinal regions in 10 patients (71.4\%) and UMN and LMN signs in 3 spinal regions without any interference in the bulbar region (28.6\%) (table 3).

TABLE 3. ALS diagnosis

\begin{tabular}{|l|c|c|}
\hline Patient's clinical signs & $\begin{array}{c}\text { Total } \\
\text { (people) }\end{array}$ & $\begin{array}{c}\text { Percentage } \\
\text { (\%) }\end{array}$ \\
\hline $\begin{array}{l}\text { - UMN and LMN sign in the } \\
\text { bulbar region and at least 2 spinal } \\
\text { regions }\end{array}$ & 10 & 71.4 \\
$\begin{array}{l}- \text { UMN and LMN sign in 3 spinal } \\
\text { regions }\end{array}$ & 4 & 28.6 \\
\hline
\end{tabular}

TABLE 4. Variation of ALS from motor nerve conduction study

\begin{tabular}{|l|l|l|l|}
\hline CMAP & $\begin{array}{l}\text { Distal } \\
\text { latention } \\
\text { (ms) }\end{array}$ & $\begin{array}{l}\text { Amplitude } \\
\text { (M-mV/S-uV) }\end{array}$ & $\begin{array}{l}\text { Nerve } \\
\text { conduction } \\
\text { velocity (m/s) }\end{array}$ \\
\hline N. medianus & $2.63 \pm 6.01$ & $0.14 \pm 8.1$ & $39.7 \pm 62.7$ \\
\hline N. ulnaris & $1.67 \pm 5.49$ & $0.12 \pm 4.8$ & $45.6 \pm 78.3$ \\
\hline N. radialis & $2.64 \pm 9.89$ & $0.36 \pm 7.0$ & $24.4 \pm 108$ \\
\hline N. peroneus & $3.86 \pm 25.2$ & $0.045 \pm 4.2$ & $36.0 \pm 58.5$ \\
\hline N. tibialis & $3.77 \pm 9.52$ & $1.75 \pm 20.4$ & $33.1 \pm 56.8$ \\
\hline
\end{tabular}


TABLE 5. Variation of ALS from sensory nerve conduction study

\begin{tabular}{|l|l|l|l|}
\hline CMAP & $\begin{array}{l}\text { Distal } \\
\text { latention (ms) }\end{array}$ & $\begin{array}{l}\text { Amplitude } \\
\text { (M-mV/S-uV) }\end{array}$ & $\begin{array}{l}\text { Nerve } \\
\text { conduction } \\
\text { velocity (m/s) }\end{array}$ \\
\hline N. medianus & $2.31 \pm 4.18$ & $0.34 \pm 30.8$ & $37.2 \pm 66.1$ \\
\hline N. ulnaris & $2.38 \pm 3.41$ & $4.4 \pm 34.2$ & $45.6 \pm 68.4$ \\
\hline N. radialis & $2.01 \pm 5.06$ & $2.1 \pm 13.5$ & $32.3 \pm 85.4$ \\
\hline N. suralis & $3.63 \pm 6.29$ & $1.32 \pm 5.9$ & $26.7 \pm 48.8$ \\
\hline
\end{tabular}

The results of the motor and sensory nerve conduction studies examination showed a description of the mixed type variant (tables 4 and 5).

TABLE 6. Variation of mean ALS in the results of the motor nerve conduction studies

\begin{tabular}{|l|c|c|c|c|}
\hline CMAP & $\begin{array}{c}\text { Median } \\
\text { distal } \\
\text { latention } \\
\text { (ms) }\end{array}$ & $\begin{array}{c}\text { Median } \\
\text { amplitude } \\
\text { (M-mV/S- } \\
\mathbf{u V})\end{array}$ & $\begin{array}{c}\text { Average } \\
\text { (m/s) }\end{array}$ & Conclusion \\
\hline N. medianus & $\begin{array}{c}4.40 \\
\text { Normal }\end{array}$ & $\begin{array}{c}3.1 \\
\text { Decreased }\end{array}$ & $\begin{array}{c}53.43 \\
\text { Normal }\end{array}$ & $\begin{array}{c}\text { Axial } \\
\text { lesions }\end{array}$ \\
\hline N. ulnaris & $\begin{array}{c}3.20 \\
\text { Normal }\end{array}$ & $\begin{array}{c}2.74 \\
\text { Decreased }\end{array}$ & $\begin{array}{c}51.41 \\
\text { Normal }\end{array}$ & $\begin{array}{c}\text { Axial } \\
\text { lesions }\end{array}$ \\
\hline N. peroneus & $\begin{array}{c}2.38 \\
\text { Normal }\end{array}$ & $\begin{array}{c}1.96 \\
\text { Decreased }\end{array}$ & $\begin{array}{c}62.29 \\
\text { Normal }\end{array}$ & Normal \\
\hline Lengthwise & $\begin{array}{c}1.15 \\
\text { Decreased }\end{array}$ & $\begin{array}{c}45.13 \\
\text { Decreased }\end{array}$ & $\begin{array}{c}\text { Mixed } \\
\text { lesions }\end{array}$ \\
\hline N. tibialis & $\begin{array}{c}5.80 \\
\text { Normal }\end{array}$ & $\begin{array}{c}7.06 \\
\text { Normal }\end{array}$ & $\begin{array}{c}48.4 \\
\text { normal }\end{array}$ & Normal \\
\hline
\end{tabular}

TABLE 7. Variation of mean ALS in the results of the sensory nerve conduction studies

\begin{tabular}{|l|c|c|c|c|}
\hline CMAP & $\begin{array}{c}\text { Median } \\
\text { distal } \\
\text { latention } \\
\text { (ms) }\end{array}$ & $\begin{array}{c}\text { Median } \\
\text { amplitude } \\
\text { (M-mV/S- } \\
\mathbf{u V} \text { ) }\end{array}$ & $\begin{array}{c}\text { Median } \\
\text { nerve } \\
\text { conduction } \\
\text { velocity } \\
\text { (m/s) }\end{array}$ & Conclusion \\
\hline $\begin{array}{l}\text { N. } \\
\text { medianus }\end{array}$ & $\begin{array}{c}3.34 \\
\text { Normal }\end{array}$ & $\begin{array}{c}12.88 \\
\text { Decreased }\end{array}$ & $\begin{array}{c}50.5 \\
\text { Normal }\end{array}$ & $\begin{array}{c}\text { Axial } \\
\text { lesions }\end{array}$ \\
\hline N. ulnaris & $\begin{array}{c}2.83 \\
\text { Normal }\end{array}$ & $\begin{array}{c}12.53 \\
\text { Decreased }\end{array}$ & $\begin{array}{c}52.54 \\
\text { Normal }\end{array}$ & $\begin{array}{c}\text { Axial } \\
\text { lesions }\end{array}$ \\
\hline N. radialis & 2.80 & 6.04 & 56.14 & Normal \\
\hline N. suralis & $\begin{array}{c}4.66 \\
\text { Lengthwise }\end{array}$ & $\begin{array}{c}4.51 \\
\text { Decreased }\end{array}$ & $\begin{array}{c}39.3 \\
\text { Decreased }\end{array}$ & $\begin{array}{c}\text { Mixed } \\
\text { lesions }\end{array}$ \\
\hline
\end{tabular}

The median result from motor and sensory nerve conduction studies show normal results, neuropathy of active and mixed types at several examination locations (tables 6 and 7).

Table 8 shows that for the diagnosis of ALS there is PSW +4, fibrillation +4, MUAP: high amplitude (giant potential), widened duration, polyphasic phase, incomplete IP recruitment in all patients (100\%) even though the muscles are different from those of patients with carried out an examination.
TABLE 8. Needle EMG result

\begin{tabular}{|c|c|c|c|c|}
\hline Musculus & PSW +4 & $\begin{array}{c}\text { Fibrilation } \\
+4\end{array}$ & $\begin{array}{l}\text { MUAP: } \\
\text { Giant } \\
\text { potential, } \\
\text { wide } \\
\text { duration, } \\
\text { polyphasic } \\
\text { phase }\end{array}$ & Incomplete \\
\hline $\begin{array}{l}\text { m. inteross } \\
\text { dorsalis I }\end{array}$ & $100 \%$ & $100 \%$ & $70 \%$ & $100 \%$ \\
\hline $\begin{array}{l}\text { m. abductor } \\
\text { digiti mini }\end{array}$ & $100 \%$ & $100 \%$ & $75 \%$ & $100 \%$ \\
\hline $\begin{array}{l}\text { m. abd policus } \\
\text { brevis }\end{array}$ & $100 \%$ & $100 \%$ & $67 \%$ & $100 \%$ \\
\hline $\begin{array}{l}\text { m. biceps } \\
\text { brachii }\end{array}$ & $100 \%$ & $100 \%$ & $80 \%$ & $100 \%$ \\
\hline $\begin{array}{l}\text { m. deltoid } \\
\text { posterior }\end{array}$ & $100 \%$ & $100 \%$ & $88 \%$ & $100 \%$ \\
\hline m. trapezius & $100 \%$ & $100 \%$ & $100 \%$ & $100 \%$ \\
\hline m. masseter & $100 \%$ & $100 \%$ & $80 \%$ & $100 \%$ \\
\hline $\begin{array}{l}\text { m. } \\
\text { genioglossus }\end{array}$ & $100 \%$ & $100 \%$ & $80 \%$ & $100 \%$ \\
\hline m. buccinator & $100 \%$ & $100 \%$ & $100 \%$ & $100 \%$ \\
\hline $\begin{array}{l}\text { m. flexor carpi } \\
\text { radialis }\end{array}$ & $100 \%$ & $100 \%$ & $67 \%$ & $100 \%$ \\
\hline $\begin{array}{l}\text { m. } \\
\text { gastrocnemius } \\
\text { caput medialis }\end{array}$ & $100 \%$ & $100 \%$ & $100 \%$ & $100 \%$ \\
\hline
\end{tabular}

\section{DISCUSSION}

The results showed that the age range of 47 years with a minimum age of 24 years and a maximum age of 63 years. The onset of ALS can occur from adolescence to age 80 years, but the peak incidence age occurs at ages 55-75 years. The mean sporadic onset of ALS (SALS) was 65 years, the mean familial onset of ALS (FALS) was 46 years $(4,5)$.

The incidence of ALS was higher in men than in women, with an overall ratio of 1.5 to 2:1 (5). However, in this study men and women were the same. The aetiology of ALS itself is not known with certainty, the same as other neurodegenerative diseases, it is possible that ALS occurs due to the complex interactions of various cellular pathogenic mechanisms such as: Genetic factors, excitotoxicity, oxidative stress, mitochondrial dysfunction, axonal transport disorders, neurofilament aggregation, protein aggregation, inflammatory dysfunction and contribution of non-neural cells, and the presence of deficits in neurotropic factors and signalling pathway dysfunction $(1,6)$.

Most types of work were unemployed as many as 7 patients (50\%). This happens because the patient comes who has experienced weakness in the legs or arms so that the patient is unable to work. The most data obtained were 13 patients (92.8\%) with married status and the latest education was high school graduates, namely 10 patients (71.4\%). It is known that ALS has major consequences not 
only for the patient but also for the family (7). Until now there is no definite data on ALS sufferers in Indonesia.

The mean interval for patients with symptoms until finally diagnosed as ALS was 5 years (baseline at mean age 42 years) with weakness in the lower extremities appearing first in 9 patients (64.3\%). The diagnosis of ALS is based on clinical findings. A person is suspected of having ALS if the loss of motor function is gradual or progressive in one or more parts of the body, without sensory disturbances and without a clear cause. ALS diagnosis according to the El Escorial criteria for ALS diagnosis is (2-4):

1. UMN and LMN signs in the bulbar region and at least 2 spinal regions, or

2. UMN and LMN signs in 3 spinal regions.

It is known that in this study, there was a diagnosis of UMN and LMN ALS signs in the bulbar region and at least 2 spinal regions in 10 patients (71.4\%) and UMN and LMN signs in 3 spinal regions without any interference in the bulbar region (28.6\%).

On sensory nerve conduction examination, the value is normal or close to normal. Abnormal conduction can be seen in entrapment neuropathy and other peripheral nerve disorders. Sensory nerve responses in the lower extremities can be difficult to obtain in the elderly $(2,3)$. In this study, the results of motor and sensory nerve conduction as a whole showed normal results, neuropathy of active and mixed types. This shows that the average patient has experienced both motor and sensory conduction problems.

The results of a concentric needle electromyography (EMG) examination will provide the evidence of LMN dysfunction necessary to support the diagnosis of ALS and should identify at least two of the four CNS regions: brain (bulbar), neck, thoracic, or lumbosacral spinal cord (anterior horn motor neuron). For the brainstem area it is sufficient to show a change in one muscle EMG (eg tongue, facial muscles, jaw muscles). For the spinal cord region the thoracic region is sufficient to show EMG changes either in the paraspinal muscles at or below the T6 level or in the abdominal muscles. For the neck and lumbosacral cord region at least two muscles innervated by different roots and peripheral nerves should show EMG changes (3).

The revised El-Escorial criteria require that both evidence of active or ongoing denervation and chronic partial denervation are required for the diagnosis of ALS, although the relative proportions vary from muscle to muscle. The signs of active denervation include: Fibrillation and positive sharp waves. Signs of chronic denervation include: large motor unit action potential (MUAP) with increasing duration, polyphasic, often increasing amplitude. Decrease in interference pattern with firing rate higher than $10 \mathrm{~Hz}$ (unless there is a prominent UMN sign, the firing rate may be lower than $10 \mathrm{~Hz}$ ) and unstable MUAP (4).

The fasciculation potential is very important as a characteristic feature of ALS especially when long duration and polyphasic features are obtained; the absence of fasciculations raises doubts but does not rule out the diagnosis, but these features in EMG are considered helpful in the diagnosis of ALS (6).

This study is in accordance with the theory obtained that for the diagnosis of ALS there is PSW +4, fibrillation +4 , MUAP: high amplitude (giant potential), widened duration, polyphasic phase, incomplete IP recruitment in all patients (100\%) even though in muscle different from the patient underwent the examination.

ALS is a fatal disease. Median life span is $3-5$ years from clinical onset of weakness. From the research, it is known that when symptoms appear, the average is 5 years until diagnosed with the initial symptoms of weakness in the lower extremities first. This suggests that the patient's prognosis is good because about $4-30 \%$ of patients with ALS can survive about 5 years after diagnosis, and about $4 \%$ survive for more than 10 years. Long-term survival was associated with younger age at onset, male, and region affected. ALS affected the extremities is said to last 3-5 years and bulbar 2-3 years $(7,8)$.

\section{CONCLUSION}

Overall results of the motor and sensory nerve conduction studies show the results of both active and mixed-type neuropathies. With the EMG picture of the needle, the presence of PSW +4 , fibrillation +4, MUAP: high amplitude (giant potential), widened duration, polyphasic phase, incomplete IP recruitment in all patients (100\%) even though the muscles were different from the patients being examined. This shows that the patient has a good prognosis.

\section{Acknowledgment}

This work was supported by Department of Neurology, Faculty of Medicine, Udayana University. 


\section{REFERENCES}

1. Ingre C, Roos PM, Piehl F, Kamel F, Fang F. Risk factors for amyotrophic lateral sclerosis. Clin Epidemiol. 2015;7:181-93.

2. Beard JD, Kamel F. Military service, deployments, and exposures in relation to amyotrophic lateral sclerosis etiology and survival. Epidemiol Rev. 2015;37(1):55-70.

3. Bozzoni V, Pansarasa O, Diamanti L, Nosari G, Cereda C, Ceroni M. Amyotrophic lateral sclerosis and environmental factors. Funct Neurol. 2016;31(1):7-19.

4. Hardiman O, Van Den Berg LH, Kiernan MC. Clinical diagnosis and management of amyotrophic lateral sclerosis. Nat Rev Neurol. 2011;7(11):639-49.
5. Zarei S, Carr K, Reiley L, Diaz K, Guerra O, Altamirano PF, et al. A comprehensive review of amyotrophic lateral sclerosis. Surg Neurol Int. 2015;6(1).

6. Martin S, Al Khleifat A, Al-Chalabi A. What causes amyotrophic lateral sclerosis? F1000Research. 2017;6.

7. Hobson EV, McDermott CJ. Supportive and symptomatic management of amyotrophic lateral sclerosis. Nat Rev Neurol. 2016;12(9):526-38.

8. Gordon PH. Amyotrophic lateral sclerosis: An update for 2013 clinical features, pathophysiology, management and therapeutic trials. Aging Dis. 2013;4(5):295-310. 